\title{
RECOMMENDATIONS CONCERNING THE ENERGY PARAMETERS SELECTION FOR MOBILE NETWORKS RADIO REPEATERS
}

\author{
${ }^{1}$ Andriy N. Derkach, ${ }^{2}$ Sergiy A. Skriabin, ${ }^{2}$ Vyacheslav I. Noskov \\ ${ }^{1}$ Lifecell company \\ ${ }^{2}$ Institute of telecommunication systems \\ Igor Sikorsky Kyiv Polytechnic Institute, Kyiv, Ukraine
}

\begin{abstract}
Background. UMTS networks which belong to $3 \mathrm{G}$ standard help to solve the problem of mobility of different types of devices such as: POS-terminals, smartphones, sensors. Networks of this type have enough channel capacity. However, quality of radio coverage has sufficient impact on these networks. Installation of radio repeaters may be a solution to the problem of coverage quality along with proper planning of the placement of base stations. However, when using radio repeaters, enough attention should be paid to determining their power, type and parameters of antenna equipment, proper installation, since ignoring this can lead to interference and poor quality of service for subscribers of this cell.
\end{abstract}

Objective. The purpose of this article is providing the method and practical recommendations concerning calculations of the energetic parameters of the radio repeaters in order to avoid interference in mobile networks.

Methods. Study known publications and standards concerning UMTS radio subsystem. Based on the requirements for receiving signal level at the receiver input of the base station and using statistical Okumura-Hata model concerning the signal attenuation in the different environments, calculate requirements for Equivalent Isotropic Radiated Power (EIRP).

Results. Tables with EIRP requirements for urban, suburban and rural conditions depending on distance to base station.

Conclusions. Methods of research and results may be used during the project process, installation and under operation process of radio repeater in mobile networks.

Keywords: UMTS; radio repeater; EIRP; statistical Okumura-Hata model; base station.

Nowadays UMTS network is actively used to provide a variety of user needs from voice calls up to access to Internet services. Since connecting subscribers to the network occurs through electromagnetic waves the quality of services mostly depends on the power flux density at points of reception. Ensuring adequate power flux density is a significant problem especially in urban environments. High-rise buildings made of reinforced concrete dense buildings significantly weakens the signals from both base stations (BS) and from the subscriber terminals. Other building materials can also reduce the signal strength of the cellular base station. Older buildings such as churches often block cellular signals. Any building that has a significant thickness of concrete walls and ceilings or a large amount of metal used for its construction will attenuate the signal. In such conditions there are even places of "gap" in the radio coverage and radio shadow areas where it becomes impossible to obtain the services of a mobile operator. In suburban and rural areas various types of interference affect the quality of the radio access network to a lesser extent. However, in such areas the deployment of a dense base stations network is economically impractical due to the low density of subscribers. In this case the signals from the BS overcome a significant path to the subscriber significantly losing their power in free space, forests overcoming the natural landforms. In all three cases (urban, suburban and rural) the simplest and most cost-effective method of locally improving the radio coverage of a cellular network is to use radio repeaters. A radio repeater is a bidirectional amplifier of mobile signals (the first direction is from the subscriber to the base station; the second direction is from the base station to the subscriber). Devices of this type in contrast to the subscriber terminal do not have automatic power control by commands from the base station. This circumstance leads to the fact that the signal power at the input of 
the BS from the radio repeater can be very high and thus cause deterioration of signal reception of subscriber terminals due to the appearance of combinational components in the nonlinear radio path of BS and reduce its gain due to automatic control system. Therefore, to eliminate the negative impact of the radio repeater on the operation of the cellular network is to ensure the level of its signal at the input of the base station within the signal average level from the subscriber equipment. Repeaters can be installed at different distances from the base station (from hundreds of meters if the subscribers are located in highly "shielded" rooms and up to 10-15 kilometers if the subscribers are in rural areas). Hence there is the problem of determining the optimal power settings radio repeater. The energy parameters that affect the signal level at the input of the BS which is the power of the transmitter and the gain of its antenna are often combined into one parameter - the equivalent isotropic radiated power (EIRP).

$$
\text { EIRP } \mathrm{dBm}=\mathrm{P}_{\mathrm{TRX}}+\mathrm{G}
$$

where: $P_{\text {TRX }}$ - power of transmitter; $G-$ gain of the antenna.

Resolving this issue is important because the correct settings of radio repeater can significantly improve mobile network coverage without specifying any obstacles in the mobile network.

The requirements for the EIRP of the radio repeater can be calculated as follows:

$$
\mathrm{EIRP}=V_{r x \mathrm{BS}}+\alpha_{\mathrm{OH}}-G_{\mathrm{BS}}[\mathrm{dBm}]
$$

where: $\mathrm{V}_{\mathrm{rxBS}}-$ sensitivity of receiver of the base station; $\alpha_{O H}-$ radio signal attenuation factor calculated over OkamuraHata propagation model $[1]$; $G_{\mathrm{BS}}$-gain of the base station antenna.

The statistical propagation model of Okumura-Hata provides formulas for calculating the attenuation coefficient of the radio signal for three main types of terrain: urban, suburban and rural. This model is used to determine the signal loss from subscriber equipment on the path of radio waves. Because a radio repeater is a device for amplifying signals from subscriber devices this model can be used to determine the propagation loss of radiation from a radio repeater. The formula for calculating the attenuation for the city is as follows:

$\alpha O H C=6955+2616 \log f-$ $1382 \log h b s-\alpha(h m s)+$ $(449-655 \log h b s) \log R \quad[\mathrm{~dB}]$ where: f-operational frequency band of radio waves; $h_{\mathrm{bs}}$-altitude of the base station antenna; $h_{\mathrm{ms}}$-altitude of mobile station; $R$ distance to the serving base station; $\alpha\left(\mathrm{h}_{\mathrm{ms}}\right)$ correctional index of mobile station antenna altitude if it differences of standard equal to 1.5 meters [2].

In turn the correction factor $\alpha$ (hms) is used only to calculate the distribution losses in the city. For a city of medium size (up to 100 thousand population) it is calculated by the following ratio:

$$
\alpha(h \mathrm{~ms})=(111 \log f-07) h \mathrm{~ms}-
$$

(1 $56 \log f-0$ 8) [dB].

The calculation of the adjustment factor when calculating the losses in a large city (population over 100 thousand people) is carried out according to the formula: [dB].

$$
\alpha(h \mathrm{~ms})=32(\log 1175 h \mathrm{~ms})^{2}-497
$$

The variables in the above formulas are identical to the variables in the formula for calculating distribution losses in the city. Distribution losses in the suburbs are calculated as: [dB]

$$
\alpha O H S=\alpha O H C-2 \log \left(\frac{f}{28}\right)^{2}-54
$$

$$
\text { where: } \quad \alpha O H C \text {-propagation loss }
$$
calculated for city.

Distribution losses in rural areas are determined by the following ratio:

$$
\alpha O H R=\alpha O H C-478(\log f)^{2}+
$$

$1833 \log f-4094[\mathrm{~dB}]$

where: $\quad \alpha O H C$-propagation loss calculated for city.

The calculation of EIRP will be performed for three types of base stations according to their range in accordance with the specification ITU-R M.1801-2 [3]: local (up to 1000 meters); medium (from 1000 to 5000 meters); large (from 5000 to 15000 meters). Base stations of local range are deployed mainly in cities; middle - in the suburbs; large - mainly in rural areas.

To further perform the calculation of the EIRP of the radio repeater it is necessary to determine such a parameter as the data rate between the subscriber equipment and the base station. For access to such services as web surfing, data transfer in messengers, video streaming a speed should not be less than 1 Mbps. Specification ITU-R M.1801-2 determines the reference sensitivity for the voice traffic transmission using AMR codecs at a transmission rate of $12.2 \mathrm{kbps}$. Sensitivities parameters are given in table. 1. 
Table 1. Sensitivity of the BS receiver when transmitting voice traffic

\begin{tabular}{|l|c|c|}
\hline \multicolumn{1}{|c|}{ BS type in according to range } & Standard channel throughput, kbps & Standard sensitivity, dBm \\
\hline Large & $12.2 \mathrm{kbps}$ & -121 \\
\hline Middle & $12.2 \mathrm{kbps}$ & -111 \\
\hline Local & $12.2 \mathrm{kbps}$ & -107 \\
\hline
\end{tabular}

In data transmission mode sensitivity level should be higher for $10 * \log (B / 12.2)$, where $B$ - data transmission speed in kbps. Hence for data transmission speed 1 Mbps (1000 kbps) sensitivity level should be higher for: $10 \lg (1000 / 12$ 2) $=19 \mathrm{~dB}$.
Information about sensitivity level of BS receiver for speed $1 \mathrm{Mbps}$ are given in Table 2.

Table 2. The sensitivity of the BS receiver for transmitting data speed $1 \mathrm{Mbps}$

\begin{tabular}{|l|c|c|}
\hline \multicolumn{1}{|c|}{ BS type in according to range } & Standard channel throughput, kbps & Standard sensitivity, dBm \\
\hline Large & $1000 \mathrm{kbps}$ & -102 \\
\hline Middle & $1000 \mathrm{kbps}$ & -92 \\
\hline Local & $1000 \mathrm{kbps}$ & -88 \\
\hline
\end{tabular}

Modern base stations are equipped with antennas with a gain of $18-20 \mathrm{~dB}$. To calculate the EIRP the gain of the BS antenna $19 \mathrm{~dB}$ is used. Calculation results for different types of area and corresponding requirements for EIRP of radio repeaters are given in tables $3 \ldots 5$. Distance step size for local base stations was chosen taking into account high density between $\mathrm{BS}$ in cities.

Table 3. Requirements for EIRP radio are repeated for city:

\begin{tabular}{|c|c|c|}
\hline$R[$ Meters $]$ & $\alpha O H C[\mathrm{~dB}]$ & EIRP $[\mathrm{dBm}]$ \\
\hline 100 & 95 & -12 \\
\hline 200 & 108 & 1 \\
\hline 300 & 115 & 8 \\
\hline 400 & 121 & 14 \\
\hline 500 & 125 & 18 \\
\hline 600 & 129 & 22 \\
\hline 700 & 131 & 24 \\
\hline 800 & 134 & 27 \\
\hline 900 & 136 & 29 \\
\hline 1000 & 138 & 31 \\
\hline
\end{tabular}

Table 4. Requirements for EIRP radio repeater for suburbs:

\begin{tabular}{|c|c|c|}
\hline$R[$ Meters $]$ & $\alpha O H \mathrm{~S}[\mathrm{~dB}]$ & EIRP $[\mathrm{dBm}]$ \\
\hline 1000 & 126 & 15 \\
\hline 1500 & 134 & 23 \\
\hline 2000 & 139 & 28 \\
\hline 2500 & 143 & 32 \\
\hline 3000 & 147 & 36 \\
\hline 3500 & 150 & 39 \\
\hline 4000 & 152 & 41 \\
\hline
\end{tabular}




\begin{tabular}{|l|l|l|}
\hline 4500 & 154 & 43 \\
\hline 5000 & 156 & 45 \\
\hline
\end{tabular}

Table 5. Requirements for EIRP radio repeater for rural areas:

\begin{tabular}{|c|c|c|}
\hline$R[$ Meters $]$ & $\alpha O H \mathrm{R}[\mathrm{dB}]$ & EIRP $[\mathrm{dBm}]$ \\
\hline 5000 & 136 & 15 \\
\hline 5500 & 138 & 17 \\
\hline 6000 & 139 & 18 \\
\hline 6500 & 141 & 20 \\
\hline 7000 & 142 & 21 \\
\hline 7500 & 144 & 23 \\
\hline 8000 & 145 & 24 \\
\hline 8500 & 146 & 25 \\
\hline 9000 & 147 & 26 \\
\hline 9500 & 148 & 27 \\
\hline 10000 & 149 & 28 \\
\hline 10500 & 150 & 29 \\
\hline 11000 & 151 & 30 \\
\hline 11500 & 152 & 31 \\
\hline 12000 & 153 & 32 \\
\hline 12500 & 153 & 32 \\
\hline 13000 & 154 & 33 \\
\hline 13500 & 155 & 34 \\
\hline 14000 & 156 & 35 \\
\hline 14500 & 156 & 35 \\
\hline 15000 & 157 & 36 \\
\hline
\end{tabular}

If the calculations show that the EIRP of the repeater radio is higher than the EIRP which can be achieved even with the use of non-directional antennas it is necessary to use attenuators with appropriate attenuation. Attenuators are installed at the output of the transmitter. When choosing an attenuator should take into account the amount of attenuation of the signal in the feeder to the donor antenna as well as the allowable dissipated power of the attenuator. If it is not possible to provide the required EIRP using a non-directional antenna it is necessary to install a directional antenna with a gain sufficient to achieve a given EIRP. In this case it is also necessary to take into account the losses in the feeder path between the radio repeater and the donor antenna.

\section{Conclusions}

1. The given approaches and results of calculations of radio repeater EIRP can be used for radio repeaters practical application in mobile networks in order to avoid the interferences.

2. The recommendations given in the article are universal for all types of radio repeaters.

3. In any cases it is necessary to carry out testing after installation of the radio repeater to be sure if interferences are absent.

\section{References}

1. A.Sibille C. Oestges A. Zanella MIMO from theory to implementation.: Academic press 2011;

2. E.Dahlman S.Parkvall J.Skold 4G LTE advanced pro and the road to 5G.: Academic press 2016;

3. ITU-R Specification M.1801-2. 
Деркач А.М., Скрябін С.А., Носков В.I. Рекомендації щодо вибору енергетичних параметрів радіо повторювачів для мереж мобільного зв'язку

Проблематика. Мережі UMTS, що підпадають під стандарт 3G, допомагають вирішувати проблему мобільності різного роду пристроїв: банківських терміналів, смартфонів, датчиків. Мережі даного типу володіють достатньою канальною ємністю. Однак, істотний вплив на надання якісних послуг в UMTSмережах має якість радіо покриття. Вирішенням проблеми якості покриття, поряд із якісним плануванням розміщення базових станцій, $є$ застосування радіо повторювачів. Однак слід приділяти достатньої уваги визначенню їхньої потужності, типу та параметрів антенного обладнання, правильній установці, адже нехтування цими діями може призводити до завад та погіршення якості обслуговування решти абонентів даного стільника.

Мета досліджень. Метою даної статті є надання методики та практичних рекомендацій щодо розрахунку енергетичних параметрів радіо повторювачів, що забезпечують відсутність створення завад в мобільній мережі.

Методика реалізації. Аналіз відомих публікацій та стандартів, присвячених принципам роботи радіопідсистеми мобільного зв'язку. На основі відомих вимог до рівнів сигналів на вході приймача базової станції та з використанням статистичної моделі Окамура-Хата відносно згасань сигналу в різних умовах розповсюдження розраховуються вимоги до еквівалентної ізотропно випромінюваної потужності (ЕІВП) радіо повторювача.

Результати досліджень. Таблиці значень потрібної ЕІВП для умов міста, передмістя та сільської місцевості в залежності від відстаней до базової станції.

Висновки. Методика досліджень та одержані результати можуть бути використані у процесі проектування, встановлення та експлуатації радіо повторювачів в мережах мобільного зв'язку.

Ключові слова: UMTS; радіо повторювач; ЕIBП; статистична модель Окамура-Хата; базова станція.

Деркач А.Н., Скрябин С.А., Носков В.И.

Рекомендации относительно выбора энергетических параметров радио повторителя для сетей мобильной связи

Проблематика. Сети UMTS, которые соответствуют стандарту 3G, помогают решать проблему мобильности разного рода устройств: банковских терминалов, смартфонов, датчиков. Сети данного типа владеют достаточной канальной емкостью. Однако, существенное влияние на предоставление качественных услуг в UMTS-сетях имеет качество покрытия. Решением проблемы качества покрытия наряду 3 правильным планированием размещения базовых станций является использование радио повторителей. Однако, при использовании радио повторителей следует уделять достаточно внимания определению их мощности, типу и параметров антенного оборудования, правильной установке, так как игнорирование этого может привести к помехам и ухудшению качества обслуживания абонентов данной соты.

Цель исследований. Целью данной статьи является предоставление методики и практических рекомендаций по расчету энергетических параметров радио повторителей, при которых обеспечивается отсутствие создания помех в мобильной сети.

Методика реализации. Анализ известных публикаций и стандартов, посвященных принципам работы радиоподсистем мобильной связи. На основе известных требований к уровням сигналов на входе приемника базовой станции и с использованием статистической модели Окамура-Хата относительно затухания сигнала в разных условиях распространения рассчитываются требования к эквивалентной изотропно излучаемой мощности (ЭИИМ) радио повторителя.

Результаты исследований. Таблицы значений требуемой ЭИИМ для условий города, пригорода и сельской местности в зависимости от расстояний до базовой станции.

Выводы. Методика исследований и полученные результаты могут быть использованы в процессе проектирования, установки и эксплуатации радио повторителей в сетях мобильной связи.

Ключевые слова: UMTS; радио повторитель; ЭИИМ; статистическая модель Окамура-Хата; базовая станция. 